\title{
Effects of FDI on Capital Account and GDP: Empirical Evidence from India
}

\author{
Sushant Sarode \\ Indian Institute of Management Indore \\ Indore 453331, India \\ Tel: 91-809-740-8066 E-mail:p10sushants@iimidr.ac.in
}

\author{
Received: December 27, 2011 \\ Accepted: March 2, 2012 Published: April 16, 2012 \\ doi:10.5539/ijbm.v7n8p102 \\ URL: http://dx.doi.org/10.5539/ijbm.v7n8p102
}

\begin{abstract}
Foreign Direct Investment (FDI) is boomed post reform in India. FDI inflows changed not only the domestic investment but also the trade situation. Then it related to balance of payments tightly. This paper aims to find the link between FDI and its impact on Indian economy. In this paper, data of some variables affecting current account balance and capital \& financial account balance from 1997 to 2011 is used to generate some results. I have utilized Granger causality test and impulse response function to analyze effect of FDI to capital and financial accounts and GDP of India. The empirical results indicate that FDI has a negative effect on current account and a positive effect on capital account.
\end{abstract}

Keywords: FDI, GNP, Granger Causality Test, Impulse Response Functions

\section{Introduction}

Indian economy has witnessed booming FDI following the balance-of-payment crisis in 1991. Liberalization of FDI and portfolio rules was done gradual manner with large number of incremental changes to large number of rules. The growth of the capital account, and the shift toward less government control of the flows, has generated increasing difficulties in terms of reconciling currency policy and monetary policy autonomy with the increasingly open capital account. The search for a sustainable framework for augmenting investment through current account deficits has as yet not been achieved. Due to change in foreign policy and investment regime post reform era, Indian economy is witnessing a steady growth in FDI during past few years. The evidence is mixed on existence of positive spillover effects of FDI for a host country, yet the positive role of FDI is well documented in literature.

The rest of the paper organized as follows: section 2 presents literature review, section 3 sets up the model framework and describes data sources; section 4 presents the empirical results, section 5 is the Granger causality tests; section 6 is impulse response function; section 6 concludes the paper.

\section{Literature Review}

FDI and its impact have drawn attention of scholars lately. Chakraborty and Basu (2002) suggest that GDP in India is not Granger caused by FDI and the causality runs more from GDP to FDI. Fry and Claessens (1995) suggest that the more liberal is a country's foreign exchange system the more likely is FDI to be exogenous or independent. Ghosh and Ostry( 1995) has argued that using vector auto-regression analysis current account in developing countries acts as a buffer to smooth consumption in the face of shocks and capital mobility may after all be quite high in this group of countries. Jansen, K. (1995) tried to assess the channels of macroeconomic impact and their intensity and suggested that export-oriented DFI is likely to have a positive effect on private investment and growth, but can have adverse balance-of-payments consequences using Thailand as example. Sahoo and Mathiyazhagan (2002) suggested that there is a long-run relationship between Gross Domestic Product (GDP), FDI, and Export (EX) and Industrial Production (IIP), FDI, and EX and also argued that FDI does not matter in the growth of the economy, but EX contributes to the growth in India.

There are several studies which are focused on the case of developing countries and the major part of them stress that FDI, adjusted to other determinants, have a significant positive effect on economic growth. In the present paper I have taken the economies of India and time period is taken from 1996 to 2011 to study the impact of FDI on GDP, current account and capital account. 


\section{Model Framework and Data Sources}

In the regression analysis, current account and capital account of the balance of payments are used as the explained variables. All the possible variables are quoted in the equation. Then, best regression fit is obtained based on the analysis of D.W. AIC (Akaike Information Criterion) and SC (Schwarz Criterion).

This paper uses indicators affecting the current account and capital and financial account from 1997 to 2011 to establish a model. CA, KA, FDI, GDP represent current account balance, capital and financial account balance, foreign direct investment and gross national product. The sample is from year 1997 to 2011. Table 1 represents sample statistics for each of these variables. The related data is from Reserve Bank of India database and Indian statistical database. The original model is:

$$
\begin{gathered}
\mathrm{KA}=\beta 0+\beta 1 \mathrm{CA}+\beta 2 \mathrm{FDI}+\beta 3 \mathrm{GDP}+\varepsilon \\
\text { Insert Table } 1-\text { here }
\end{gathered}
$$

\section{Empirical Results}

I have used the Augmented Dickey-Fuller (ADF) unit-root tests. This is because of the ADF unit-root tests give the most reliable results. There are three types of different conditions in the ADF test for every time series. First, random process includes intercept (c) and trend ( $\mathrm{t}$ ). Second, random process includes intercept (c) but no trend $(0)$. Third, random process includes no intercept $(0)$ and trend $(t)$. The results of the test indicates that all the variables, capital account, current account balance, foreign direct investment and gross national product all have a unit root in their levels and are stationary in their first differences.

\section{Insert Table 2- here}

From the Table 2, we can see that all variables have unit roots in their level. That is, they are instable. So, we respectively do first and second order difference to all the variables using Eviews-5.1 to do regression analysis based on the data; the results are presented in Table 3 and 4.

Using Eviews5.0 to do regression analysis based on the data and removing the non-extinct variables, the result is present in table 3.

Insert Table 3- here

From Table 3, the t-statistics of FDI and GDP are extinctive and also the F-statistic is extinctive too. It suggests that the regression equation fits very well. From the analysis we get a CA model

$$
\begin{gathered}
\mathrm{CA}=7095.953-1.136292 \mathrm{FDI}-0.00976 \mathrm{GDP} \\
\text { Insert Table 4- here }
\end{gathered}
$$

From the Table 4, we can see that all the variables are extensive and the model fits well. From the resultant equation we know the T-statistics of GDP, CA, FDI are extinctive. The R-squared is big and the F-statistic is extinctive, so we can say that the model fits well, the D-W statistic is also well in range and shows positive serial correlation among the variables. From the analysis we get a KA model:

$$
\mathrm{KA}=0.037132 \mathrm{CA}-2.518097 \mathrm{FDI}+0.098731 \mathrm{GDP}-28887.23
$$

\section{Granger Causality Test}

We use Granger causality test to analyze the relationship between the variables further. The Granger causality tests results in Eviews5.0 are shown in Table 5. When the lag=2, the Granger cause between CA and FDI does not exist. It suggests that the cause effect of FDI to CA is not extinctive. Maybe the samples are limited which lead to the non-extinctive results, or maybe the lags are different. But in short term, FDI is the Granger cause of CA. This means FDI contributes a lot to CA.

$$
\text { Insert Table 5- here }
$$

\section{Impulse Response Function}

VAR is estimated and its dynamic structure is characterized using impulse response function. The impulse response can do this by showing how shocks to any one variable filter through the model to affect every other variable and eventually lead back to the original variable itself. Figure 1 shows impulse responses functions. The horizontal spool delegates trace periods of the response function and the vertical spool delegate responses of dependent variable to independent variables. In Figure 1, solid lines stand for calculate values of response functions, dashed line is response function values plus or minus double standard deviation confidence lines.

From Figure 1 we can see the impulse response function of FDI to CA. When we introduce a positive one-period 
shock to FDI, the response of CA is not extinctive. Only after a long period dose it appears negative effect. It suggests that FDI has a negative effect to CA in the long period. Also when we introduce a positive one-period shock to CA, the response of FDI is not extinctive too. But in the long period it rises slowly. We know the shock of FDI to KA has a positive effect. It even promotes this kind of positive effect trends to be stable gradually. It suggests that FDI has an extinctive positive effect to KA.

\section{Insert Figure 1- here}

\section{Conclusion}

This research reveals that FDI affect the CA and GDP a lot. FDI Granger cause current account deficits or vice versa. All the variables GDP, CA, FDI relate to KA a lot. Both the regression model fit well. The negative impact of FDI on CA has come into picture for India. The impulse response function analysis indicates that FDI has a negative effect on CA. It suggests that FDI promotes the current account deficit. We expect to find FDI has a positive relationship of KA by Granger causality test. The test results are not extinctive. This may be because of the multiple deficits in current account balance which leads up to trade account deficits as well.

\section{References}

Ahmad Mohsin H., Shaista A., \& Mohammad S. B. (2004). Foreign Direct Investment, Exports and Domestic Output in Pakistan. Pakistan Development Review, 42(4), 715-723.

Asma S., \& Hui X. F. (2009). Negative Impact of FDI: A Cointegrated Approach. The International Journal of Organizational Innovation, 2, 272-282.

Athreye, S., \& Kapur, S. (2001). Private Foreign Investment in India: Pain or Panacea?. The World Economy, 24(3), 399-424. http://dx.doi.org/10.1111/1467-9701.00362

Bekaert, G., Harvey, C. R., \& Lundblad, C. (2003). Equity market liberalization in emerging markets. [Online] Available: http://ssrn.com/abstract $=795345$

Chakraborty, C., \& Basu, P. (2002). Foreign direct investment and growth in India: A cointegration approach. Applied Economics, 34, 1061-1073. http://dx.doi.org/10.1080/00036840110074079.

Fry, M., Claessens, S., Burridge, P., \& Blanchet, M. (1995). Foreign Direct Investment, Other Capital Flows and Current Account Deficits: What Causes What?. Working Paper no. 1527 (World Bank Policy Research).

Ghosh, A., \& Ostry, J. D. (1995). The Current Account in Developing Countries: a Perspective from Consumption Smoothing Approach. World Bank Economic Review, 9(2), 305-333. http://dx.doi.org/10.1093/wber/9.2.305

Granger, C. W. J. (1986). Developments in the Study of the Cointegrated Economic Variables. Oxford Bulletin of Economics and Statistics, 48, 201-212.

Gulzar, S., \& Hui, X. F. (2006). Thirty years of chronic current account deficit 1972-2001: The case of Pakistan. J. Harbin Inst. Technol., 14, 259-264.

Jansen, K. (1995). The Macroeconomic Effects of Direct Foreign Investment: The Case of Thailand. World Development, 23, 193-210. http://dx.doi.org/10.1016/0305-750X(94)00125-I

Klein, M. W., \& Olivei, G. P. (2008). Capital account liberalization, financial depth, and economic growth. Journal of International Money and Finance, 27, 861-875. http://dx.doi.org/10.1016/j.jimonfin.2008.05.002

Kumar, N., \& Pradhan, J. P. (2002). Foreign Direct Investment, Externalities and Economic Growth in Developing Countries: Some Empirical Explorations and Implications for WTO Negotiations on Investment. RIS Discussion Papers 27.

Root, Franklin, R., \& Ahmed. (1979). Empirical Determinants of DFI in Developing Countries. Economic Development and Cultural Change, 27(4). http://dx.doi.org/10.1086/451139

Sahoo, D., \& Mathiyazhagan, M. K. (2002). Economic Growth in India: Does Foreign Direct Investment Inflow Matter? Working Papers 115 (Institute for Social and Economic Change. Bangalore). 
Table 1. Sample Statistics for each variable (US mn\$)

\begin{tabular}{|c|c|c|c|c|}
\hline Year & CA & KA & FDI & GDP \\
\hline $1996-1997$ & -5956 & 11412 & 2141 & 388343 \\
\hline $1997-1998$ & -2965 & 10011 & 2770 & 410915 \\
\hline $1998-1999$ & -6903 & 8260 & 3682 & 416252 \\
\hline $1999-2000$ & -3228 & 11100 & 3083 & 450476 \\
\hline $2000-2001$ & -4601 & 8840 & 2439 & 460182 \\
\hline $2001-2002$ & 1410 & 8551 & 2463 & 477848 \\
\hline $2002-2003$ & 6345 & 10840 & 4065 & 507189 \\
\hline $2003-2004$ & 14083 & 16736 & 2705 & 599461 \\
\hline $2004-2005$ & -2470 & 28022 & 2188 & 721573 \\
\hline $2005-2006$ & -9902 & 25470 & 3219 & 834035 \\
\hline $2006-2007$ & -9565 & 45203 & 5540 & 951339 \\
\hline $2007-2008$ & -15737 & 106585 & 12492 & 1242426 \\
\hline $2008-2009$ & -27915 & 6768 & 24575 & 1213782 \\
\hline $2009-2010$ & -38383 & 53397 & 27330 & 1380640 \\
\hline $2010-2011$ & -44281 & 59747 & 25834 & 1729010 \\
\hline
\end{tabular}

Table 2. Unit Root Test Statistics

\begin{tabular}{|c|c|c|c|c|c|c|}
\hline \multirow{2}{*}{ Variable } & \multirow{2}{*}{ Lags } & \multirow{2}{*}{ ADF Test Statistic } & \multicolumn{3}{|c|}{ Test Critical Values at Different } & \multirow{2}{*}{ Probability } \\
\cline { 4 - 6 } & & & $1 \%$ & $5 \%$ & $10 \%$ & \\
\hline KA & 0 & -2.664 & -4.004 & -3.099 & -2.690 & 0.105 \\
\hline$\Delta$ KA & 0 & -6.413 & & & & 0.000 \\
\hline CA & 0 & 0.732 & -4.004 & -3.099 & -2.690 & 0.988 \\
\hline$\Delta$ CA & 0 & -2.603 & & & & 0.117 \\
\hline FDI & 4 & 0.169 & -4.297 & -3.213 & -2.748 & 0.954 \\
\hline$\Delta$ FDI & 4 & -0.677 & & & & 0.804 \\
\hline GDP & 1 & 2.638 & -4.058 & -3.120 & -2.701 & 1.000 \\
\hline$\Delta$ GDP & 1 & -1.130 & & & & 0.666 \\
\hline
\end{tabular}

Table 3. Regression Results of using CA as explained variable

\begin{tabular}{|c|c|c|c|}
\hline Variable & Regression Coefficient & Standard Error & t-Statistic \\
\hline C & 7095.953 & 4830.944 & 1.468854 \\
\hline FDI & -1.136292 & 0.418516 & -2.71505 \\
\hline GDP & -0.00976 & 0.009331 & -1.04598 \\
\hline R-squared & 0.847072 & Akaike info criterion & 20.63358 \\
\hline Adjusted R-squared & 0.821584 & Schwarz criterion & 20.77519 \\
\hline Durbin-Watson stat & 1.017848 & F-statistic & 33.2341 \\
\hline
\end{tabular}


Table 4. Regression Results

\begin{tabular}{|c|c|c|c|}
\hline Variable & Regression Coefficient & Standard Error & t-Statistic \\
\hline C & -28887.23 & 14267.77 & -2.024649 \\
\hline CA & 0.037132 & 0.784929 & 0.047306 \\
\hline FDI & -2.518097 & 1.445853 & -1.741600 \\
\hline GDP & 0.098731 & 0.026503 & 3.725199 \\
\hline R-squared & 0.668914 & Akaike info criterion & 22.68048 \\
\hline Adjusted R-squared & 0.578618 & Schwarz criterion & 22.86929 \\
\hline Durbin-Watson stat & 2.66511 & F-statistic & 7.408009 \\
\hline
\end{tabular}

Table 5. Pairwise Causality Test $(\mathrm{Lags}=2)$

\begin{tabular}{|l|c|c|c|}
\hline Null Hypothesis: & Obs & F-Statistic & Probability \\
\hline GDP does not Granger Cause KA & \multirow{2}{*}{13} & 2.45681 & 0.14729 \\
& & 6.76359 & 0.01907 \\
\hline KA does not Granger Cause GDP & \multirow{2}{*}{13} & 27.2508 & 0.00027 \\
\cline { 1 - 1 } & & 0.66949 & 0.53847 \\
\hline KA does not Granger Cause FDI & \multirow{2}{*}{13} & 2.12783 & 0.18156 \\
\cline { 1 - 1 } FDI does not Granger Cause KA & \multirow{2}{*}{13} & 0.46393 & 0.64472 \\
\cline { 1 - 1 } KA does not Granger Cause CA & & 14.2864 & 0.00229 \\
\hline FDI does not Granger Cause GDP & \multirow{2}{*}{13} & 1.45531 & 0.28904 \\
\cline { 1 - 1 } GDP does not Granger Cause FDI & & 0.51224 & 0.61755 \\
\hline FDI does not Granger Cause CA & \multirow{2}{*}{13} & 3.68496 & 0.0734 \\
\cline { 1 - 1 } CA does not Granger Cause FDI & & 0.09226 & 0.91282 \\
\hline GDP does not Granger Cause CA & & & 0.00993 \\
\hline CA does not Granger Cause GDP & & &
\end{tabular}




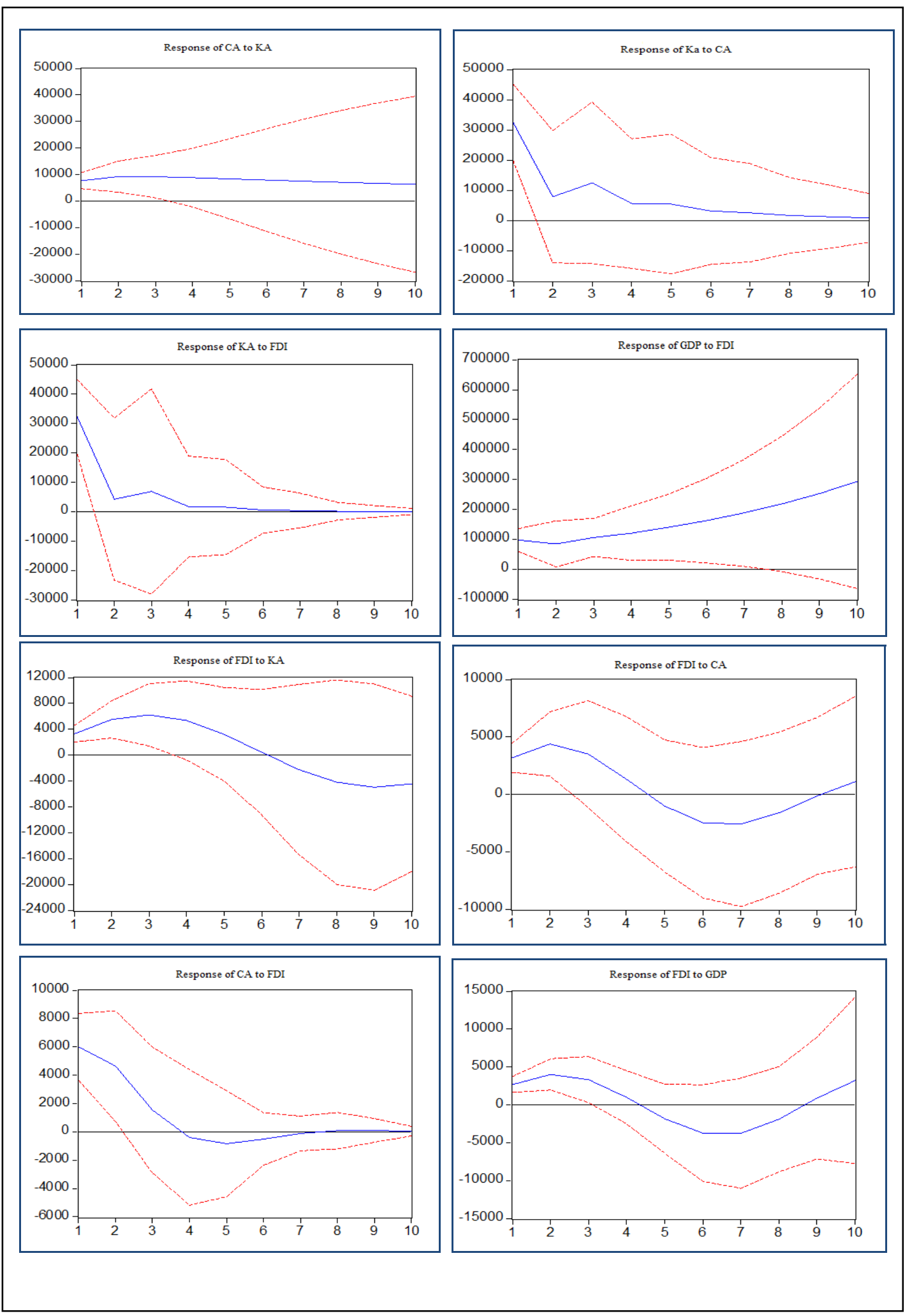

Figure 1. Impulse Response Functions

Source: Reserve Bank of India database and http://www.indiastat.com/default.aspx 